\title{
Studi dan Evaluasi Operasional Pelayaran Perintis di Indonesia
}

\author{
Rudi.S.Suyono ${ }^{1}$ Elsa Trimukti ${ }^{2}$ \\ 1. Dosen Fakultas Teknik Jurusan Sipil Universitas Tanjungpura
}

\begin{abstract}
Abstrak
Pelayanan transportasi keperintisan adalah sebagai unsur pendorong (promoting) menyediakan jasa transportasi yang efektif untuk menghubungkan daerah terisolasi dengan daerah berkembang yang berada di luar wilayahnya dan/atau luar negeri, sehingga terjadi pertumbuhan perekonomian yang sinergis. Selain itu, pelayanan kapal perintis tersebut diselenggarakan untuk mewujudkan fokus kerja Kementerian Perhubungan yaitu peningkatan keselamatan dan keamanan, peningkatan kualitas pelayanan, dan peningkatan kapasitas. Berdasarkan hasil analisis disparitas yang cukup tinggi terjadi di wilayah timur Indonesia antara lain di Tanah Bumbu, Kepulauan Anambas, Natuna, Tanjung Pinang, Bima, Ambon, Kepuluauan Aru, Maluku Barat Daya, Seram Bagian Barat, Tual, Halmahera Barat, Halmahera Selatan, Halmahera Tengah, Halmahera Timur, Halmahera Utara, Kepulauan Sula, Pulau Morotai, Pulau Taliabu, Ternate, Asmat, Boven Digul, Mappi, Merauke, dan Mimika. Disparitas tertinggi yaitu sebesar 114\% terjadi pada tahun 2017 untuk bahan pokok di wilayah Maluku, tepatnya di Kepulauan Aru, Maluku Barat Daya, dan Tual. Dari sampel trayek yang diamati didapat bahwa rata-rata passenger factor untuk setiap voyage berada di rentang $1 \%$ hingga $13 \%$ saja dengan tingkat keterisian penumpang maksimum pada satu voyage sebesar $45.5 \%$. Sementara, rata-rata load factor untuk setiap voyage berada di rentang $0.2 \%$ hingga $28 \%$ dengan tingkat keterisian barang maksimum pada satu voyage sebesar $103.5 \%$. Berdasarkan identifikasi konektivitas antara trayek angkutan laut perintis dengan simpul pelabuhan tol laut, tampak bahwa masih ada ketimpangan konektivitas antara jaringan angkutan laut perintis dengan simpul pelabuhan tol laut. Konektivitas simpul pelabuhan tol laut dengan angkutan laut perintis paling tinggi ada di Pelabuhan Saumlaki, dengan 16 trayek terkoneksi dengan pelabuhan ini.
\end{abstract}

Kata kunci: studi tinjau ulang, jaringan angkatan laut,kontuinitas kebutuhan bahan pokok dan stabilitas harga

\begin{abstract}
The pioneering transportation service is an element of promoting providing effective transportation services to connect isolated areas with developing regions that are outside their territory and / or abroad, so that there is a synergistic economic growth. In addition, the pioneer ship service was carried out to realize the work focus of the Ministry of Transportation, namely improving safety and security, improving service quality, and increasing capacity. Based on the results of the analysis of fairly high disparities in eastern Indonesia, among others in Tanah Bumbu, Anambas Islands, Natuna, Tanjung Pinang, Bima, Ambon, Kepuluauan Aru, Southwest Maluku, Seram Bagian Barat, Tual, Halmahera Barat, Halmahera Selatan, Halmahera Tengah, East Halmahera, North Halmahera, Sula Islands, Morotai Island, Taliabu Island, Ternate, Asmat, Boven Digul, Mappi, Merauke, and Mimika. The highest disparity is 114\% in 2017 for staples in the Maluku region, precisely in the Aru Islands, Southwest Maluku, and Tual. From the sample routes observed, it was found that the average passenger factor for each voyage was in the range of $1 \%$ to $13 \%$ with a maximum passenger occupancy rate of one voyage of $45.5 \%$. Meanwhile, the average load factor for each voyage is in the range of $0.2 \%$ to $28 \%$ with the maximum level of goods load on one voyage of $103.5 \%$. Based on the identification of connectivity between pioneer sea transport routes and the sea toll port node, it appears that there is still a connectivity gap between the pioneering sea transport network and the sea toll port node. The connectivity of the sea toll port node with the highest pioneer sea transportation is in Saumlaki Port, with 16 routes connected to this port.
\end{abstract}

Keywords: eview studies, naval networks, basic needs and price stability 


\section{Pendahuluan}

Dalam Sistranas dikatakan bahwa pelayanan transportasi keperintisan adalah sebagai unsur pendorong (promoting) menyediakan jasa transportasi yang efektif untuk menghubungkan daerah terisolasi dengan daerah berkembang yang berada di luar wilayahnya dan/atau luar negeri, sehingga terjadi pertumbuhan perekonomian yang sinergis. Berdasarkan peraturan dan ketentuan yang ada, penyelenggaraan angkutan laut perintis dilakukan untuk:

1. Menghubungkan daerah-daerah terpencil dan belum berkembang;

2. Menghubungkan daerah yang belum memiliki moda transportasi lain secara memadai;

3. Menghubungkan daerah yang secara komersial belum menguntungkan untuk dilayani pelayaran niaga.

Dengan pola penyelenggaraan semacam itu, angkutan laut perintis berfungsi untuk menghubungkan satu daerah terpencil atau belum berkembang dengan daerah yang belum berkembang lainnya, serta dengan daerah yang sudah berkembang. Selain itu, pelayanan kapal perintis tersebut diselenggarakan untuk mewujudkan fokus kerja Kementerian Perhubungan yaitu peningkatan keselamatan dan keamanan, peningkatan kualitas pelayanan, dan peningkatan kapasitas. Hal ini juga sebagai wujud komitmen Kementerian Perhubungan untuk menjalankan program Nawacita ke-3 Presiden Republik Indonesia, yaitu membangun Indonesia dari pinggiran dengan memperkuat daerah- daerah dan desa dalam kerangka negara kesatuan.

Lamanya round voyage kapal-kapal perintis dirasakan masih belum memadai untuk memenuhi kebutuhan masyarakat, terutama yang berada di daerah- daerah Tertinggal, Terdepan dan Terluar. Kelangkaan barangbarang kebutuhan pokok sering terjadi dan harga barangbarang tersebut menjadi tinggi dan sering tidak terkendali.

Dalam program Nawacita, dikatakan bahwa untuk menghubungkan dan merekat pulau-pulau Indonesia dilakukan dengan Tol Laut. Tujuan Tol Laut adalah mengatasi kelangkaan barang-barang kebutuhan pokok dan memperkecil terjadinya disparitas harga, antara daerah-daerah Tertinggal, Terdepan, dan Terluar dengan daerah pusat produksi.

Berdasarkan konsep pelayaran perintis dan program Tol Laut, terdapat kesamaan cita-cita/ ide, yaitu mengembangkan daerah-daerah Tertinggal, Terdepan, dan Terluar, terutama pada wilayah-wilayah kepulauan. Pada sisi lain kedua program tersebut sama-sama

rudisuyono.rs@gmail.com

elsatrimukti.faisal@gmail.com mendapat subsidi pemerintah.

Beberapa pertayaan yang muncul terkait penyelenggaraan angkutan laut perintis adalah sebagai berikut:

1. Bagaimana konektivitas angkutan perintis dengan angkutan niaga lainya termasuk tol laut yang optimum untuk menjaga kontinuitas kebutuhan barang pokok agar stabilitas harga terjaga?

2. Bagaimana pengoperasian dan jaringan angkutan laut perintis yang optimum di wilayah terdepan, terluar, dan terisolir?

3. Bagaimana dapat terwujudnya kesamaan misi antara angkutan pelayaran perintis dan tol laut untuk melayani masyarakat kepulauan yang berada di wilayah terdepan, terluar, dan terisolir?

Dengan demikian, Badan Penelitian dan Pengembangan Perhubungan melalui Pusat Penelitian dan Pengembangan Transportasi Laut, Sungai, Danau, dan Penyeberangan bermaksud melakukan kegiatan tinjau ulang terhadap pengoperasian dan jaringan angkutan laut perintis yang bertujuan untuk memberikan masukan terhadap pelayanan angkutan laut perintis yang lebih efektif dan efisien, sehingga menjaga kontinuitas kebutuhan bahan pokok dan stabilitas harga terutama pada daerah tertinggal, terdepan, dan terluar.

\section{Pendekatan dan Metode}

Hal pertama yang dilakukan adalah diperlukannya pendekatan melalui aspek-aspek yang relevan dalam rangka mengidentifikasi faktor-faktor kajian dan lingkup kebutuhan datanya. Merujuk pada lingkup kajian dan keterlibatan tenaga ahli yang diperlukan, maka pendekatan kajian dilakukan terhadap beberapa aspek yaitu aspek teknis, aspek ekonomi, aspek supply \& demand dan aspek kebijakan. Selanjutnya dilakukan Pengumpulan data sekunder yang dilakukan melalui survei kepustakaan, meliputi dasar-dasar teori, referensireferensi, serta peraturan perundang- undangan, yang terkait dan relevan dengan studi. Dilanjutkan dengan pengumpulan data primer yang dilakukan melalui survei lapangan di beberapa lokasi yang terkait dan relevan, yang dimungkinkan melalui kuesioner sebagai panduan yang telah disusun sebelumnya.

Pada tahap selanjutnya dilanjutkan dengan analisis data yang sudah ada berupa analisis proyeksi dan estimasi pertumbuhan potensi wilayah hinterland pelabuhan, analisis proyeksi dan estimasi pertumbuhan arus muatan, analisis dan evaluasi kebutuhan dan disparitas harga barang-barang kebutuhan pokok, analisis proyeksi dan estimasi kebutuhan infrastruktur pelabuhan, analisis aksesibilitas lokasi terhadap Kawasan hinterland, analisis dan evaluasi terhadap jaringan/trayek yang sudah beroperasi, dan analisis konektivitas dengan simpul pelabuhan Tol Laut. Sehingga dihasilkan rekomendasi mengenai konsep pelayanan angkutan laut perintis yang 
lebih efektif dan efisien, sehingga dapat menjaga kesinambungan kebutuhan bahan pokok dan stabilitas harga terutama pada daerah tertinggal, terdepan, dan terluar.

\section{Jaringan Trayek Angkatan Laut Perintis di Wilayah Studi}

Jaringan trayek angkutan laut perintis yang beroperasi saat ini diatur berdasarkan Keputusan Direktur Jenderal

Perhubungan Laut Nomor AL. 108/5/20/DJPL-17 tentang Perubahan Atas Keputusan Direktur Jenderal

Perhubungan Laut Nomor AL. 108/5/11/DJPL-17 tentang Jaringan Trayek Angkutan Laut Perintis Tahun Anggaran 2018. Saat ini, angkutan laut perintis melayani 22 provinsi di Indonesia di 41 pelabuhan pangkal dengan jumlah trayek sebanyak 113. Pada tahun 2017 angkutan perintis terlayani 96 trayek. Pengoperasian angkutan laut perintis dilaksanakan berdasarkan trayek tetap dan teratur atau liner dengan jadwal kedatangan dan keberangkatan di setiap pelabuhan singgah diumumkan oleh Perusahaan Angkutan Laut Nasional sebagai operator kapal.

Dalam penelitian ini pengumpulan data hanya dilakukan di enam pangkalan yang mencakup 21 trayek angkutan laut perintis. Pangkalan yang menjadi wilayah studi adalah pangkalan Teluk Bayur, Surabaya, Sintete, Ternate, Poso dan Kolonedale, dan Merauke.

Dari hasil kategorisasi daerah 3T diperoleh bahwa dari 121 pelabuhan singgah di wilayah studi terdapat 80 pelabuhan yang masuk dalam wilayah 3T. Sementara 41 pelabuhan tidak termasuk dalam wilayah 3T. Untuk 80 pelabuhan yang terdapat pada wilayah $3 \mathrm{~T}$ yang dirinci: sebanyak 63 pada wilayah tertinggal, 12 pada wilayah terdepan dan terluar, serta 5 wilayah termasuk dalam kategori tertinggal, terdepan, dan terluar.

Berdasarkan kategorisasi di atas dapat dikatakan, bahwa penyelenggaraan angkutan laut perintis masih sesuai dengan tujuannya seperti disebutkan dalam Peraturan Pemerintah Nomor 20 Tahun 2010 tentang Angkutan di Perairan Pasal 71 ayat 1 bahwa kegiatan pelayaran perintis dilakukan untuk menghubungkan daerah yang masih tertinggal dan/atau wilayah terpencil yang belum berkembang dengan daerah yang sudah berkembang atau maju.

3.1. Evaluasi Jarak dan Waktu Tempuh Pada tabel dibawah ini disajikan rekapitulasi hasil perbandingan realisasi jarak, hari layar, dan frekuensi per tahun dengan rencana operasi trayek angkutan laut perintis pada tahun 2018 di wilayah studi. Dari hasil analisis dan evaluasi jarak dan waktu tempuh pada trayek angkutan laut perintis yang beroperasi di wilayah studi diperoleh bahwa lama round voyage trayek angkutan laut perintis dapat dikatakan terlalu lama, melebihi 2 minggu pelayaran yaitu berkisar antara 11 19 hari pelayaran.

\subsection{Evaluasi Passenger Factor dan Load Factor}

Diperoleh bahwa besarnya rata-rata passenger factor di setiap voyage untuk trayek R3 berkisar antara $39 \%$ sampai $109 \%$. Nilai minimum passenger factor adalah sebesar $0 \%$ dan nilai maksimum tingkat keterisiannya sebesar 222,5\%. Hal ini menunjukkan bahwa tingkat keterisian kapal perintis trayek R3 telah melebihi kapasitas penumpangnya yaitu sebesar 40 penumpang saja. Hal ini wajar mengingat kapal yang digunakan trayek R3 adalah bekas kapal barang sehingga kapasitas penumpangnya hanya sedikit, untuk itu perlu dilakukan penyesuaian ukuran kapal. Sementara, besarnya rata-rata load factor di setiap voyage untuk trayek R3 berkisar antara $19.3 \%$ sampai $19.4 \%$. Nilai minimum load factor adalah sebesar $0 \%$ dan nilai maksimum tingkat keterisiannya sebesar $41.2 \%$. Hal ini menunjukkan bahwa tingkat keterisian kapal perintis trayek R3 tidak melebihi kapasitas penumpangnya yaitu sebesar 750 ton. Hal ini wajar mengingat kapal yang digunakan trayek R3 adalah bekas kapal barang sehingga kapasitas barangnya besar.

\subsection{Evaluasi Kinerja Angkutan Laut Perintis Dari Sisi Pengguna}

Indikator kinerja pelayaran perintis pada aspek efektivitas dan efiesensi dapat dilihat dari parameter kemudahan, kapasitas, kehandalan, kualitas, keterjangkauan, beban publik, dan utilisasi. Dalam survei primer dilakukan wawancara terhadap pengguna angkutan laut perintis di pelabuhan sampel di wilayah studi baik penumpang maupun barang untuk menilai kinerja angkutan laut perintis saat ini. Beberapa indikator kinerja tersebut dituangkan dalam kuesioner dalam bahasa yang mudah dimengerti responden. Adapun lokasi wawancara dilakukan pada pelabuhan pangkal Teluk Bayur (R4), Sintete (R9), Tanjung Perak (R18), Poso, Ternate (R64) dan Merauke.

Tak jauh berbeda, dari sisi pengguna pengangkutan barang, secara keseluruhan dari sisi penumpang, sebagian besar responden menyatakan bahwa kinerja angkutan laut perintis saat ini sudah cukup baik, namun terdapat beberapa aspek yang perlu diperbaiki antara lain berkaitan dengan fasilitas di pelabuhan, frekuensi keberangkatan, rute pelayaran, dan jumlah kapal.

\subsection{Evaluasi Ruas Jaringan Angkutan laut Perintis Terhadap Moda Lain}

Terlihat bahwa beberapa ruas trayek angkutan laut perintis beriirisan dengan trayek angkutan laut perintis lainnya, sebut saja ruas Surabaya - Masalembo dan Masalembo - Keramaian yang dilayani oleh R16, R17, R18 yang berpangkal di Surabaya, Mayau - Tifure, dan Tifure - Bitung yang dilayani oleh keempat trayek yang berpangkal di Ternate yaitu R64, R65, R66, dan R67, ataupun ruas Merauke - Wanam yang dilayani oleh trayek R82, R83, R85, dan R86 yang berpangkal di Merauke. 
Selain itu ditemukan pula beberapa ruas yang tumpang tindih dengan kapal komersil seperti Letung - Tarempa, Bima - Labuan Bajo, Makassar - Bau Bau, dan Tual Dobo, dengan jalan raya yaitu Teluk Bayur - Panasahan, Sikabaluan/Pokai - Muara Saibi/Subeleng, Tua Pejat Sioban, Surabaya - Kalianget, Badas - Bima, Waikelo Waingapu, Gorontalo - Torosit, Torosit - Bitung, Poso Bau Bau, Bau Bau - Bringkasi, Baturube - Kolo, Mafa Weda, Jailolo - Bataka, Bataka - Buli, Sagoni - Atsy, dan Mur - Kepi, dan dengan tol laut yaitu ruas Tarempa Midai.

Ditemukan pula beberapa ruas yang dapat ditempuh dengan jalur darat karena tersedia jalan raya seperti Teluk Bayur - Panasahan, Sikabaluan/Pokai - Muara Saibi/Subuleleng, Tua Pejat - Sioban, Surabaya Kalianget, Badas - Bima, Waikelo - Waingapu, Gorontalo - Torosit, Torosit - Bitung, Baturube - Kolo, Mafa - Weda, Jailolo - Bataka, Atsy - Sagoni, Sagoni Eci, dan Moor - Kepi.

3.5. Evaluasi Biaya dan Subsidi Analisis biaya dan subsidi dilakukan berdasarkan RAB yang telah ada untuk menjadi harga satuan jarak (mil). Hal ini dilakukan untuk mengetahui biaya dan subsidi yang harus dikeluarkan dalam 1 mil. Diperoleh rencana biaya per mil yang perlu dikeluarkan untuk setiap trayek dalam wilayah studi tahun anggaran 2018 berkisar antara Rp 198.148,00 hingga Rp 578.710,00 sementara subsidi per mil yang perlu dianggarkan untuk setiap trayek dalam wilayah studi berkisar antara Rp 175.374,00 hingga Rp $551.289,00$.

3.6. Konektivitas Dengan Simpul Pelabuhan Tol Laut

Direktorat Jenderal Perhubungan Laut menetapkan 15 (lima belas) jaringan trayek penyelenggaraan angkutan barang di laut (Tol Laut) Tahun Anggaran 2018 melalui Keputusan Direktur Jenderal Perhubungan Laut Nomor AL.108/5/17/DJPL-17 tentang Jaringan Trayek Penyelenggaraan Angkutan Barang di Laut Tahun Anggaran 2018. Dalam Keputusan Dirjen Perhubungan Laut tersebut ari 15 trayek utama dan 3 trayek feeder dapat diidentifikasi simpul pelabuhan tol laut, yaitu sebanyak 61 simpul. Kemudian, jaringan trayek angkutan laut perintis yang beroperasi di tahun 2018 diidentifikasi konektivitasnya terhadap 61 simpul pelabuhan tersebut, tingkat konektivitas didasarkan kepada jumlah trayek yang terkoneksi dengan simpul pelabuhan tersebut.ditetapkan tambahan 2 trayek untuk tahun 2018 sehingga total berjumlah 15 trayek utama dengan yang sudah ada saat ini serta 3 trayek feeder, yaitu pada Trayek T-4 (Hub Tahuna), Trayek T-5 (Hub Tobelo) dan Trayek T-8 (Hub Biak).

\section{Kebutuhan dan Disparitas Harga Barang Pokok 4.1. Kebutuhan Barang Pokok}

Untuk menilai kinerja angkutan laut perintis saat ini, pada pelabuhan pangkal Teluk Bayur (R4), Sintete (R9), Tanjung Perak (R18), Poso, Ternate (R64) dan Merauke dilakukan wawancara terhadap responden (pengguna angkutan laut perintis) dalam mendapatkan bahan pokok.

Hasil evaluasi mengenai kebutuhan barang pokok di wilayah sekitar pelabuhan pangkal menunjukkan bahwa secara keseluruhan masyarakat dapat memperoleh barang pokok dengan mudah. Namun terdapat beberapa komoditi yang masih sulit didapatkan seperti daging sapi di Padang (Pangkalan Teluk Bayur); jagung, kedelai, kacang tanah, dan gas elpiji di Poso (Pangkalan Poso dan Kolonedale); telur ayam, cabai, bawang, dan ketela pohon di Ternate (Pangkalan Ternate); serta ketela pohon dan jagung di Merauke (Pangkalan Merauke).

4.2. Disparitas Harga Barang Pokok disparitas harga untuk setiap jenis bahan pokok yang cukup tinggi terjadi di daerah Tanah Bumbu, Kepulauan Anambas, Natuna, Tanjung Pinang, Bima, Ambon, Kepuluauan Aru, Maluku Barat Daya, Seram Bagian Barat, Tual, Halmahera Barat, Halmahera Selatan, Halmahera Tengah, Halmahera Timur, Halmahera Utara, Kepulauan Sula, Pulau Morotai, Pulau Taliabu, Ternate, Asmat, Boven Digul, Mappi, Merauke, dan Mimika. Disparitas tertinggi yaitu sebesar $114 \%$ terjadi pada tahun 2017 untuk bahan pokok cabai merah di wilayah Maluku, tepatnya di Kepulauan Aru, Maluku Barat Daya, dan Tual. Hal ini kemungkinan terjadi karena masih lamanya waktu round voyage angkutan laut perintis di daerah tersebut, sebut saja trayek R66, R84, dan R85 dengan lama round voyage 15 - 16 hari.

Meskipun demikian, adanya angkutan laut perintis dapat membantu menjaga kestabilan harga bahan pokok di daerah yang disinggahi. Sebagai contoh, untuk bahan pokok jenis beras perkembangan disparitas harga dalam periode 2016 hingga 2018 cenderung semakin menurun setiap tahunnya, meskipun di beberapa daerah sebut saja Maluku dan Maluku Utara disparitas harga beras justru meningkat Error! Reference source not found.. Bila dikaitkan dengan lamanya round voyage angkutan laut perintis, pada tahun 2018 trayek R64, R65, dan R66 yang singgah di kabupaten/kota di Maluku dan Maluku Utara membutuhkan waktu sekitar 13 - 19 hari untuk melakukan satu round voyage.

Hal ini menjelaskan bahwa keberadaan angkutan laut perintis memiliki peranan yang penting dalam menjaga kestabilan harga bahan pokok sehingga perlu dijaga dan ditingkatkan kinerjanya terutama terkait lama round voyage ataupun frekeunsi pelayarannya agar bahan pokok semakin mudah didapat dengan harga yang lebih murah. 


\section{Proyeksi dan Estimasi}

5.1. Proyeksi dan Estimasi Pertumbuhan Potensi Wilayah Hinterland Pelabuhan

Analisis potensi wilayah hinterland pelabuhan akan dilakukan dengan menggunakan parameter Produk Domestik Regional Bruto (PDRB) berdasarkan harga konstan. Estimasi potensi wilayah hinterland pelabuhan pangkalan/singgah, dihitung berdasarkan PDRB wilayah kabupaten/kota lokasi pelabuhan tersebut berada dengan menggunakan regresi linier.

Proyeksi PDRB untuk jangka pendek, menengah, dan jangka panjang menggunakan tahun dasar 2012-2016 seperti disajikan pada Tabel 5 dan Tabel 6. Potensi wilayah pada hinterland angkutan laut perintis yang digambarkan oleh PDRB atas dasar harga konstan menunjukkan peningkatan setiap tahunnya, sehingga dapat dikatakan bahwa estimasi proyeksi muatan angkutan laut perintis pun akan meningkat sejalan dengan pertumbuhan PDRB wilayahnya

Muatan

5.2. Proyeksi dan Estimasi Pertumbuhan Arus

Proyeksi muatan dilakukan pada data rata-rata naik turun penumpang dan bongkar muat barang pada tahun $2018 \mathrm{ke}$ tahun 2048 untuk setiap trayeknya di setiap pangkalan.

Dengan pendekatan laju pertumbuhan muatan sama dengan laju pertumbuhan PDRB setiap tahunnya, diperoleh hasil proyeksi naik turun penumpang dan bongkar muat barang lima tahunan pada pelabuhan singgah trayek.

5.3. Proyeksi dan Kebutuhan Infrastruktur Yang Mendukung Angkutan Laut Perintis

Analisis proyeksi dan kebutuhan infrastruktur yang mendukung angkutan laut perintis diperlukan untuk mengakomodasi muatan di masa depan, baik infrastruktur pengangkutan (kapal) maupun fasilitas pelabuhan (dermaga). Besaran proyeksi kebutuhan dilakukan berdasarkan hasil analisis proyeksi muatan angkutan laut perintis di masa depan. Analisis ini akan ditekankan pada pelabuhan pengumpul yang lebih tepat daripada pelabuhan utama. Hal ini didasari karena mayoritas pelabuhan utama merupakan pelabuhan dengan bongkar muat berupa kontainer sedangkan pada angkutan perintis tidak memuat kontainer. Disisi lain pelabuhan utama akan dirasa cukup padat jika menampung pula angkutan perintis. Oleh karena itu, pelabuhan pengumpul dirasa lebih tepat untuk dikembangkan infrastrukturnya terhadap angkutan perintis.

5.3.1. Kebutuhan Ukuran Kapal Minimum Mengacu pada hasil proyeksi on board passenger dan on board load serta standar kapasitas angkut kapal, diperoleh hasil penentuan kebutuhan ukuran kapal minimum untuk setiap trayek yang ditinjau sebagai berikut.

Tabel 14 Kebutuhan Ukuran Kapal Minimum Berdasarkan Proyeksi Penumpang (2018-2048)

\begin{tabular}{|l|l|l|l|r|r|r|r|r|r|}
\hline & & Ko & \multicolumn{6}{|c|}{ Kebutuhan Kapal Berdasarkan } \\
N & Pang & de & \multicolumn{5}{|c|}{ Proyeksi Penumpang (DWT) } \\
\cline { 3 - 10 } o & kalan & Tr & & & & & & \\
& ay & 20 & 20 & 20 & 20 & 20 & 20 & 20 \\
& & ek & 18 & 23 & 28 & 33 & 38 & 43 & 48 \\
\hline & Teluk & R3 & 20 & 20 & 20 & 20 & 20 & 20 & 35 \\
1 & Bayur & & 0 & 0 & 0 & 0 & 0 & 0 & 0 \\
\hline & Surab & R1 & 20 & 20 & 20 & 35 & 35 & 50 & 50 \\
2 & aya & 8 & 0 & 0 & 0 & 0 & 0 & 0 & 0 \\
\hline & Terna & R6 & 20 & 20 & 20 & 20 & 20 & 20 & 20 \\
3 & te & 4 & 0 & 0 & 0 & 0 & 0 & 0 & 0 \\
\hline & Terna & R6 & 20 & 20 & 20 & 20 & 20 & 20 & 20 \\
4 & te & 5 & 0 & 0 & 0 & 0 & 0 & 0 & 0 \\
\hline
\end{tabular}

Sumber: Analisis Konsultan, 2018

Tabel 15 Kebutuhan Ukuran Kapal Minimum Berdasarkan Proyeksi Barang (2018-2048)

\begin{tabular}{|l|l|c|r|r|r|r|r|r|r|}
\hline & & Ko & \multicolumn{6}{|c|}{ Kebutuhan Kapal Berdasarkan } \\
$\mathrm{N}$ & Pangk & de & \multicolumn{6}{|c|}{ Proyeksi Barang (DWT) } \\
\cline { 5 - 11 } o & alan & Tra & 20 & 20 & 20 & 20 & 20 & 20 & 20 \\
& & yek & 18 & 23 & 28 & 33 & 38 & 43 & 48 \\
\hline & Teluk & R3 & 75 & 75 & 13 & 13 & 13 & 13 & 13 \\
1 & Bayur & & 0 & 0 & 00 & 00 & 00 & 00 & 00 \\
\hline & & & 12 & 12 & 12 & 12 & 12 & 12 & 12 \\
& Surab & R1 & 00 & 00 & 00 & 00 & 00 & 00 & 00 \\
& aya & 8 & $\mathrm{G}$ & $\mathrm{G}$ & $\mathrm{G}$ & $\mathrm{G}$ & $\mathrm{G}$ & $\mathrm{G}$ & $\mathrm{G}$ \\
& & & $\mathrm{T}$ & $\mathrm{T}$ & $\mathrm{T}$ & $\mathrm{T}$ & $\mathrm{T}$ & $\mathrm{T}$ & $\mathrm{T}$ \\
\hline & Ternat & R6 & 20 & 35 & 50 & 50 & 50 & 50 & 75 \\
3 & e & 4 & 0 & 0 & 0 & 0 & 0 & 0 & 0 \\
\hline & Ternat & R6 & 20 & 20 & 20 & 20 & 20 & 20 & 20 \\
4 & e & 5 & 0 & 0 & 0 & 0 & 0 & 0 & 0 \\
\hline
\end{tabular}

Sumber: Analisis Konsultan, 2018

Tabel 16 Rekomendasi Ukuran Kapal Minimum (20182048)

\begin{tabular}{|c|l|c|r|r|r|r|r|r|r|}
\hline & & Ko & \multicolumn{7}{|c|}{ Rekomendasi Ukuran Kapal } \\
N & Pangk & de & \multicolumn{7}{|c|}{ (DWT) } \\
\cline { 4 - 10 } o & alan & Tra & 20 & 20 & 20 & 20 & 20 & 20 & 20 \\
& & yek & 18 & 23 & 28 & 33 & 38 & 43 & 48 \\
\hline & Teluk & R3 & 75 & 75 & 13 & 13 & 13 & 13 & 13 \\
1 & Bayur & & 0 & 0 & 00 & 00 & 00 & 00 & 00 \\
\hline & Suraba & R1 & 20 & 20 & 20 & 35 & 35 & 50 & 50 \\
2 & ya & 8 & 0 & 0 & 0 & 0 & 0 & 0 & 0 \\
\hline & Ternat & R6 & 20 & 35 & 50 & 50 & 50 & 50 & 75 \\
3 & e & 4 & 0 & 0 & 0 & 0 & 0 & 0 & 0 \\
\hline & Ternat & R6 & 20 & 20 & 20 & 20 & 20 & 20 & 20 \\
4 & e & 5 & 0 & 0 & 0 & 0 & 0 & 0 & 0 \\
\hline
\end{tabular}

Sumber: Analisis Konsultan, 2018

\subsubsection{Kebutuhan Dermaga}

kebutuhan panjang dermaga, kedalaman kolam dermaga, dan lebar apron minimum yang dibutuhan untuk setiap pelabuhan singgah tahun 2023 sampai 2048 berdasarkan standar yang dijelaskan pada RSNI Dermaga Untuk 
Pelayanan Kapal Perintis. Untuk trayek yang tidak dapat dihitung ukurannya karena keterbatasan data dianggap memiki ukuran yang sama dengan kapal terbesar pada trayek lain di pangkalan yang sama Mengenai perhitungan panjang dermaga minimum, jumlah tambatan ditentukan sebanyak 2 tambatan untuk pelabuhan yang disinggahi lebih dari 2 trayek perintis. Sementara hasil perhitungan kebutuhan kedalaman kolam dermaga dan lebar apron minimum pada tahun rencana yaitu 2018 hingga 2048 tidak berubah yaitu masing-masing 5 meter dan 15 meter di setiap pelabuhan yang ditinjau.

\section{Kebutuhan Re-Routing Pada Jaringan Trayek Angkutan Laut Perintis}

Dalam Peraturan Pemerintah Nomor 20 Tahun 2010 tentang Angkutan di Perairan pasal 71 (1), dijelaskan bahwa kegiatan perintis dilakukan untuk:

a. Menghubungkan daerah yang masih tertinggal dan/atau wilayah terpencil yang belum berkembang dengan daerah yang sudah berkembang atau maju;

b. Menghubungkan daerah yang moda transportasi lainnya belum memadai; dan

c. Menghubungkan daerah yang secara komersial belum menguntungkan untuk dilayani oleh pelaksana kegiatan angkutan laut, angkutan sungai dan danau, atau angkutan penyeberangan.

Dapat dikatakan, fungsi angkutan laut perintis adalah untuk menghubungkan daerah-daerah terpencil, dan menciptakan hal yang posistif terhadap perkembangan perekonomian daerah tertinggal, terpencil, dan terluar itu sendiri, serta dapat menciptakan suatu pelayaran yang teratur, tetap, serta aman.

Selanjutnya dalam peraturan yang sama yaitu pada pasal 71 (2) dijelaskan bahwa kriteria pelayaran perintis adalah:

a. Belum dilayani oleh pelaksana angkutan laut, angkutan sungai dan danau atau angkutan penyeberangan yang beroperasi secara tetap dan teratur; dan

b. Secara komersial belum menguntungkan, atau tingkat pendapatan per kapita penduduknya masih rendah.

Tujuan dan kriteria penyelenggaraan angkutan laut perintis sebagaimana yang dijelaskan pada pasal 71 ayat 1 dan 2 Peraturan Pemerintah Nomor 20 Tahun 2010 inilah yang dijadikan dasar dalam melakukan evaluasi ruas-ruas trayek dan rekomendasi re-routing angkutan laut perintis.

Pelayaran perintis harus berjalan sesuai dengan yang diharapkan, pelayanan trayeknya tidak tumpang tindih dengan pelayanan trayek komersil. Pelayanan angkutan perintis harus juga bisa melayani wilayah perbatasan. Daerah-daerah yang dianggap sudah mandiri dan mampu melaksanakan pelayaran dengan angkutan laut komersial, maka trayek angkutan perintis pada daerah tersebut dihapus dan dialihkan ke daerah lain yang membutuhkan. Selain dengan angkutan komersil, angkutan laut perintis sebaiknya juga tida tumpang tindih dengan moda jalan (jalan raya) dan angkutan tol laut.

Namun, daerah yang tadinya dianggap sudah mampu menyelenggarakan pelayaran sendiri yang didukung oleh pelayaran swasta bisa kembali dilayari oleh kapal perintis karena permintaan masyarakat. Daerah seperti Kepulauan Riau misalnya pelayaran perintis R-6 yang dihapus trayeknya karena dianggap sudah maju dan dilayari oleh pelayaran swasta, ternyata kembali dilayari oleh trayek perintis karena pelayaran swasta tidak lagi mengunjungi daerah tersebut.

Mengacu pada kriteria penyelenggaraan angkutan laut perintis pada Peraturan Pemerintah Nomor 20 Tahun 2010 akan dilakukan peninjauan kembali jaringan angkutan laut perintis di pada wilayah studi agar penyelenggaraan angkutan laut perintis dapat berjalan sesuai dengan fungsinya. Hasil tinjau ulang jaringan angkutan laut perintis berupa usulan re-routing pada trayek yang tidak memenuhi kriteria penyelenggaraan angkutan laut perintis. Selain itu re-routing ini juga diperlukan untuk mengatasi permasalahan waktu round voyage yang terlalu lama. Dalam hal ini, re-routing dilakukan agar waktu round voyage ideal yaitu 10 hari dapat tercapai.

Berikut ini adalah tahapan yang dilakukan dalam mengevaluasi dan melakukan re-routing angkutan laut perintis yang ada di wilayah studi.

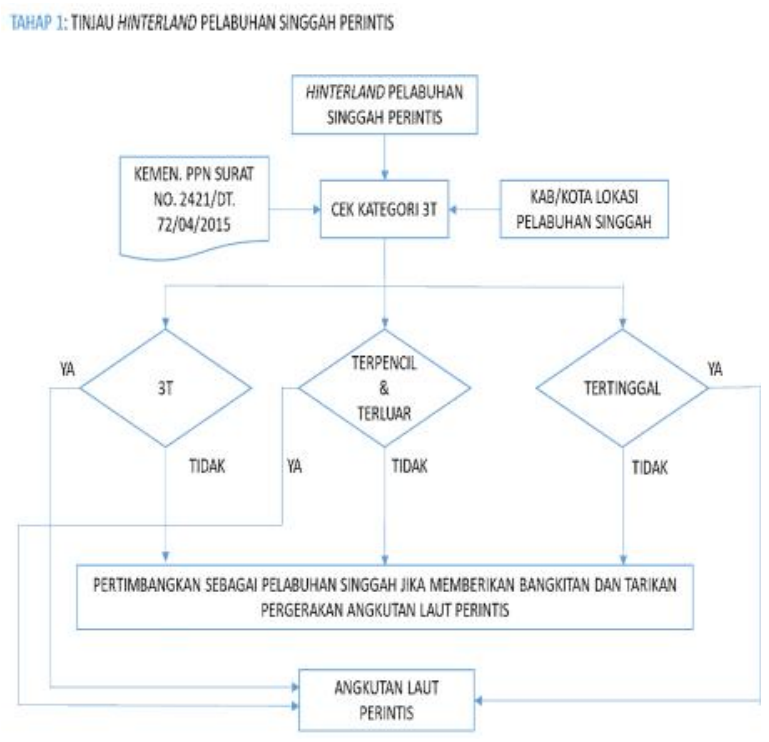


TAHAP 2: TINJAU RUAS JARINGAN ANGKUTAN LAUT PERINTIS

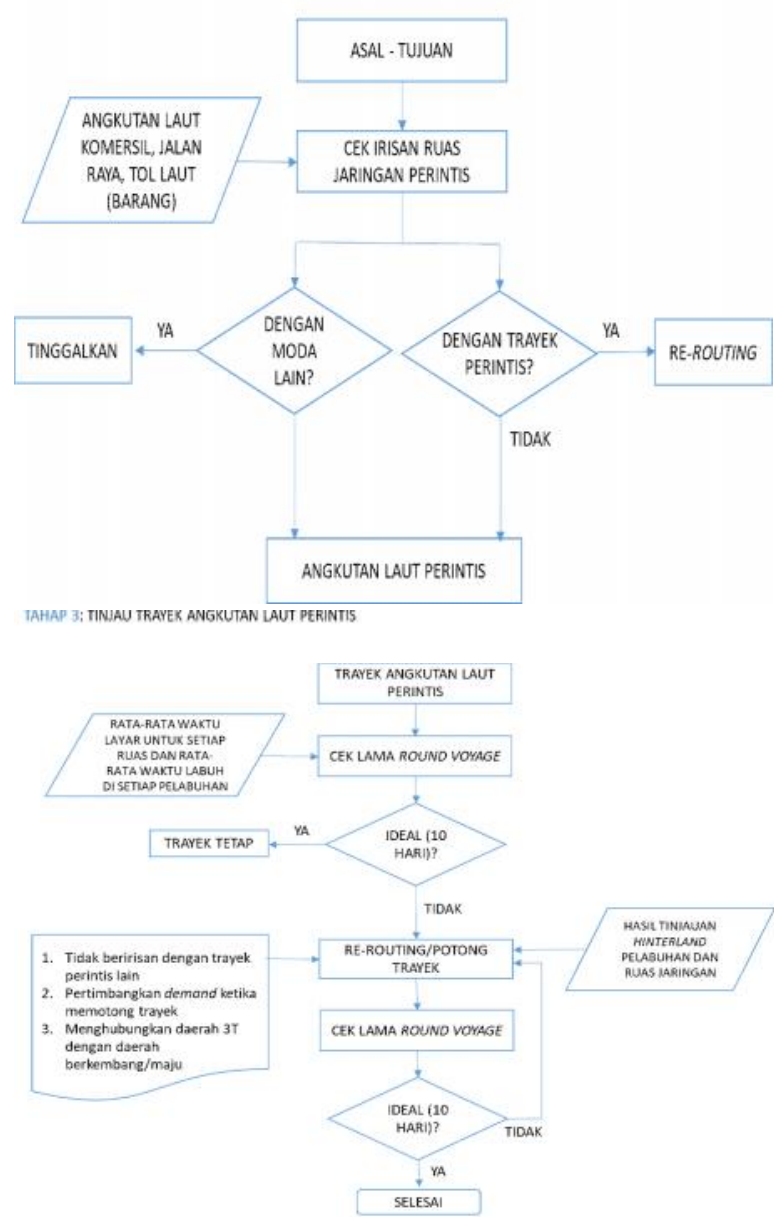

Beberapa hasil evaluasi yang didapatkan untuk trayek angkutan laut perintis yang ditinjau antara lain:

\section{a. Trayek R3 di Pangkalan Teluk Bayur}

Lama round voyage untuk trayek R3 sudah memenuhi lama round voyage ideal yaitu kurang dari 10 hari. Meskipun demikian, hasil evaluasi yang didapatkan untuk trayek R3 adalah ruas Teluk Bayur - Panasahan perlu diubah pada trayek R3 karena: beririsan dengan jalan raya dan beririsan dengan angkutan laut perintis lain.

b. Trayek R4 di Pangkalan Teluk Bayur

Diperoleh bahwa lama round voyage untuk trayek $\mathrm{R} 4$ belum memenuhi lama round voyage ideal yaitu 12 hari. Hasil evaluasi yang didapatkan pada trayek R4 adalah sebagai berikut:

- Ruas Sikalabaluan/Pokai _ Muara Saibi/Subeleng, Teluk Bayur - Panasahan, dan Tua Pejat - Sioban pada trayek R4 perlu diubah karena beririsan dengan jalan raya; dan

- Jaringan trayek R4 cenderung memutar karena menyinggahi pelabuhan Teluk Bayur dan Panasahan sebanyak tiga kali dalam satu round voyage.

\section{c. Trayek R9 di Pangkalan Sintete}

Diperoleh bahwa lama round voyage untuk trayek R9 dengan lama round voyage 9 hari sudah memenuhi lama round voyage ideal yaitu 10 hari. Meskipun demikian, hasil evaluasi yang didapatkan untuk trayek R9 adalah ruas Letung - Tarempa perlu diubah pada trayek R9 karena beririsan dengan kapal laut komersil milik PELNI.

d. Trayek R16 di Pangkalan Surabaya Diperoleh bahwa lama round voyage untuk trayek R16 belum memenuhi lama round voyage ideal yaitu 12 hari. Selain itu, dari hasil evaluasi jaringan juga didapatkan bahwa seluruh ruas jaringan trayek R16 beririsan dengan angkutan laut perintis lain dalam hal ini adalah R19. Dengan demikian, sebaiknya trayek ini dihilangkan agar penggunaan kapal perintis lebih efisien.

e. Trayek R17 di Pangkalan Surabaya Diperoleh bahwa lama round voyage untuk trayek $\mathrm{R} 17$ belum memenuhi lama round voyage ideal yaitu 12 hari. Hasil evaluasi yang didapatkan pada trayek R17 adalah sebagai berikut:

- Ruas Surabaya - Masalembo dan Masalembo Keramaian perlu diubah pada trayek R19 karena beririsan dengan trayek ini; dan

- Ruas Marabatuan - Batulicin dan Batulicin Kotabaru perlu diubah pada trayek R17 karena beririsan dengan kapal komersil milik PELNI.

f. Trayek R18 di Pangkalan Surabaya Diperoleh bahwa lama round voyage untuk trayek $\mathrm{R} 18$ dengan lama round voyage 17 hari belum memenuhi lama round voyage ideal yaitu kurang dari 10 hari. Beberapa hasil evaluasi yang didapatkan untuk trayek R18 adalah sebagai berikut:

- Ruas Surabaya - Kalianget, Badas - Bima, Waikelo - Waingapu perlu diubah pada trayek R18 karena beririsan dengan jalan raya;

- Ruas Bima - Labuan Bajo perlu diubah pada trayek R18 karena beririsan dengan kapal laut komersil milik PELNI; dan

- Ruas Kalianget - Sapudi, Sapudi - Kangean, dan Kangean - Sapeken perlu diubah pada trayek R18 karena beririsan dengan trayek angkutan laut perintis lain.

g. Trayek R19 di Pangkalan Surabaya

Diperoleh bahwa lama round voyage untuk trayek $\mathrm{R} 19$ dengam lama round voyage 14 hari belum memenuhi lama round voyage ideal yaitu 12 hari. Hasil evaluasi yang didapatkan pada trayek R19 adalah ruas Surabaya - Masalembo dan Masalembo - Keramaian perlu diubah pada beririsan dengan trayek lain.

\section{h. Trayek R29 di Pangkalan Poso}


Diperoleh bahwa lama round voyage untuk trayek R29 dengan lama round voyage 6 hari sudah memenuhi lama round voyage ideal yaitu 10 hari. Meskipun demikian, hasil evaluasi yang didapatkan untuk trayek R29 adalah Ruas Gorontalo - Torosit, Torosit - Bitung perlu diubah pada trayek R29 karena beririsan dengan jalan raya.

\section{i. Trayek R110 di Pangkalan Poso}

Diperoleh bahwa lama round voyage untuk trayek R110 sudah memenuhi lama round voyage ideal yaitu kurang dari 10 hari. Meskipun demikian, hasil evaluasi yang didapatkan untuk trayek R110 adalah sebagai berikut:

- Pelabuhan yang disinggahi pada trayek R110 bukan merupakan daerah $3 \mathrm{~T}$ namun belum memiliki moda angkutan yang memadai; dan

- Tidak ada muatan penumpang di setiap voyage, hanya Bringkasi yang menjadi asal pengangkutan barang.

\section{j. Trayek R36 di Pangkalan Kolonedale}

Diperoleh bahwa trayek R36 dengan lama round voyage 14 hari belum memenuhi lama round voyage ideal yaitu 10 hari. Hasil evaluasi yang didapatkan pada trayek R36 adalah sebagai berikut:

- Ruas Baubau - Makassar perlu diubah pada trayek R36 karena beririsan dengan jalan raya dan angkutan laut komersil; dan

- Ruas Baturube - Kolo perlu diubah pada trayek R36 karena beririsan dengan jalan raya.

k. Trayek R64 di Pangkalan Ternate Diperoleh bahwa lama round voyage untuk trayek R64 selama 18 hari belum memenuhi lama round voyage ideal yaitu kurang dari 10 hari. Beberapa hasil evaluasi yang didapatkan untuk trayek R64 adalah sebagai berikut:

- Ruas Mafa - Weda perlu diubah pada trayek R64 karena beririsan dengan jalan raya; dan

- Ruas Ternate - Soasio, Ternate - Mayau, Mayau - Tifure, dan Tifure - Bitung perlu diubah pada trayek R64 karena beririsan dengan trayek angkutan laut perintis lain.

\section{l. Trayek R65 di Pangkalan Ternate}

Diperoleh bahwa lama round voyage untuk trayek R65 selama 29 hari belum memenuhi lama round voyage ideal yaitu kurang dari 10 hari. Beberapa hasil evaluasi yang didapatkan untuk trayek R65 adalah sebagai berikut:

- Ruas Jailolo - Bataka dan Bataka - Buli perlu diubah pada trayek R65 karena beririsan dengan jalan raya; dan

- Ruas Ternate - Mayau, Mayau - Tifure, dan Tifure - Bitung perlu diubah pada trayek R65 karena beririsan dengan trayek angkutan laut perintis lain.

\section{m. Trayek R66 di Pangkalan Ternate}

Diperoleh bahwa lama round voyage untuk trayek R66 selama 12 hari belum memenuhi lama round voyage ideal yaitu 10 hari. Selain itu, dari hasil evaluasi jaringan juga didapatkan bahwa ruas Ternate - Mayau, Mayau - Bitung, Bitung - Tobelo, Tobelo dan Tobelo - Daruba perlu diubah karena beririsan dengan trayek angkutan laut perintis hasil re-routing pada R65.

\section{n. Trayek R67 di Pangkalan Ternate}

Diperoleh bahwa lama round voyage untuk trayek R67 selama 12 hari belum memenuhi lama round voyage ideal yaitu 10 hari. Selain itu, dari hasil evaluasi jaringan juga didapatkan bahwa ruas Ternate - Bataka, Bataka - Mayau, Mayau - Tifure, dan Tifure - Bitung, perlu diubah karena beririsan dengan trayek angkutan laut perintis hasil re-routing pada R65.

\section{o. Trayek R80 di Pangkalan Merauke}

Diperoleh bahwa lama round voyage untuk trayek R80 selama 13 hari belum memenuhi lama round voyage ideal yaitu 10 hari. Selain itu, dari hasil evaluasi jaringan juga didapatkan bahwa ruas Bayun - Atsy, Atsy - Sagoni, dan Sagoni - Eci perlu diubah karena beririsan dengan trayek angkutan laut perintis lain dan jalan raya.

\section{p. Trayek R81 di Pangkalan Merauke}

Diperoleh bahwa lama round voyage untuk trayek R81 selama 12 hari belum memenuhi lama round voyage ideal yaitu 10 hari. Selain itu, dari hasil evaluasi jaringan juga didapatkan bahwa ruas Moor - Kepi perlu diubah karena beririsan dengan trayek angkutan laut perintis lain.

\section{q. Trayek R82 di Pangkalan Merauke}

Diperoleh bahwa lama round voyage untuk trayek R82 selama 12 hari belum memenuhi lama round voyage ideal yaitu 10 hari. Selain itu, dari hasil evaluasi jaringan juga didapatkan bahwa ruas Merauke - Wanam dan Wanam - Bayun, perlu diubah karena beririsan dengan trayek angkutan laut perintis lain.

\section{r. Trayek R83 di Pangkalan Merauke}

Diperoleh bahwa lama round voyage untuk trayek R83 selama 13 hari belum memenuhi lama round voyage ideal yaitu 10 hari. Selain itu, dari hasil evaluasi jaringan juga didapatkan bahwa ruas Merauke - Wanam, Bayun - Atsy, dan Atsy - Eci , perlu diubah karena beririsan dengan trayek angkutan laut perintis.

S. Trayek R84 di Pangkalan Merauke Diperoleh bahwa lama round voyage untuk trayek R84 selama 12 hari belum memenuhi lama round voyage ideal yaitu 10 hari. Selain itu, dari hasil evaluasi jaringan juga didapatkan bahwa ruas Bade - Agats, Agats - Pomako, dan Dobo - Pomako perlu 
diubah karena beririsan dengan trayek angkutan laut perintis lain serta ruas Tual - Dobo perlu diubah karena beriirisan dengan trayek angkutan laut komersil milik PELNI.

\section{t. Trayek R85 di Pangkalan Merauke}

Diperoleh bahwa lama round voyage untuk trayek R85 selama 13 hari belum memenuhi lama round voyage ideal yaitu 10 hari. Selain itu, dari hasil evaluasi jaringan juga didapatkan bahwa ruas Merauke - Wanam, Bade - Agats, Agats Pomako, Dobo - Pomako, dan Pomako Agatas, perlu diubah karena beririsan dengan trayek angkutan laut perintis lain serta ruas Tual - Dobo karena beririsan dengan kapal komersil milik PELNI.

u. Trayek R86 di Pangkalan Merauke

Diperoleh bahwa lama round voyage untuk trayek R86 selama 6 hari sudah memenuhi lama round voyage ideal yaitu 10 hari. Maka, tidak dilakukan re-routing untuk trayek ini.

7.Kebutuhan Ketentuan Mengenai Kriteria dan Evaluasi Penyelenggaraan Angkutan Laut Perintis

Saat ini, peraturan mengenai keperintisan lebih banyak dijelaskan untuk angkutan perintis udara. Sebagaimana Peraturan yang telah diundangkan pada Peraturan Menteri Nomor 79 Tahun 2017 merupakan perubahan dari Peraturan Menteri Nomor 9 Tahun 2016, membahas mengenai jenis kegiatan angkutan udara perintis, kriteria rute perintis, penyelenggaraan angkutan udara perintis, pelaksanaan angkutan udara perintis, evaluasi rute perintis, serta kewajiban penyelenggara angkutan perintis.

Berdasarkan kriteria yang telah disusun oleh Direktorat Jenderal Udara, yang dipandang sudah cukup baik, maka angkutan laut perintis dapat mengacu kepada peraturan angkutan udara perintis tersebut. Maka secara kriteria untuk angkutan laut perintis dijabarkan sebagai berikut.

7.1. Penjabaran Kriteria Penetapan Rute Perintis Terutama Fungsi Perintis Untuk Menghubungkan Daerah Terpencil dan Daerah Tertinggal

Kriteria daerah terpencil dan daerah tertinggal meliputi: a. Daerah yang sulit aksesibilitas dengan ibu kota propinsi dan/atau daerah lain yang mempunyai keterhubungan secara ekonomi;

b. Daerah perbatasan dengan negara lain berdasarkan penetapan oleh Badan yang membidangi pengelolaan perbatasan;

c. Pulau-pulau kecil terluar berdasarkan penetapan Presiden; atau

d. Daerah tertinggal berdasarkan penetapan

Presiden.

Lebih lanjut dijelaskan mengenai kriteria daerah yang sulit aksesibilitas dengan ibu kota dan/atau daerah lain yang mempunyai keterhubungan secara ekonomi berupa: a. Pelayanan dan ketersediaan moda transportasi lain pada rute perintis tersebut memiliki kapasitas terbatas dibandingkan kebutuhan angkutan dan kesinambungan pelayanan tidak teratur; dan

b. Waktu tempuh yang lama dengan moda transportasi selain transportasi udara; atau

c. Keadaan di daerah yang pada waktu-waktu tertentu pelayanan moda transportasi yang sudah tersedia tidak berkesinambungan dikarenakan faktor alam dan infrastruktur yang tidak mendukung.

\subsection{Mekanisme Penetapan Rute Perintis}

Usulan rute perintis dilakukan dengan mekanisme sebagai berikut:

a. Usulan rute angkutan udara perintis diajukan oleh Koordinator Wilayah kepada Direktur Jenderal secara tertulis;

b. Usulan rute perintis terdiri dari rute lama (existing) dan rute baru disampaikan setelah berkoordinasi dengan Kantor Syahbandar dan Otoritas Pelabuhan, Unit Pelaksana Pelabuhan cakupan dan Pemerintah Daerah Setempat;

c. Usulan rute angkutan udara perintis yang diajukan oleh Koordinator Wilayah, wajib disertai dengan data kelengkapan sebagai berikut:

1. Surat pernyataan oleh Kepala Unit Penyelenggara Pelabuhan atau Koordinator Wilayah terkait tentang kesiapan operasional bandar udara pada rute-rute yang diusulkan;

2. Kerangka Acuan Kerja (Term of Referrence/TOR) dan perhitungan rincian kebutuhan anggaran biaya dalam 1 (satu) periode pelaksanaan angkutan udara perintis;

3. Data dukung untuk angkutan udara perintis penumpang berupa:

a) Data aksesibilitas dengan ibu kota propinsi dan/atau daerah lain yang mempunyai keterhubungan secara ekonomi yang meliputi:

1) Pelayanan dan ketersediaan moda transportasi lainnya meliputi: (a) jenis dan jumlah moda transportasi lainnya; dan

(b) kapasitas tiap moda transportasi.

2) Waktu tempuh dengan moda transportasi lainnya;

3) Kondisi kesinambungan pelayanan moda transportasi lainnya; dan

4) Data potensi keterhubungan secara ekonomi ditunjukkan dengan:

(a) Besarnya Pendapatan Daerah Regional Bruto (PDRB) daerah tersebut yang dirinci per sektor;

(b) Analisa ekonomi apabila tersedia angkutan udara perintis pada rute tersebut; 
b) Data lokasi daerah sesuai dengan penetapan daerah terpencil, terluar dan perbatasan;

c) Data bandar udara terkait;

d) Jumlah potensi permintaan angkutan udara perintis dibagi atas:

1) Profesi masyarakat; dan

2) Tujuan melakukan kegiatan perjalanan.

e) Hasil koordinasi dengan Kantor Syahbandar dan Otoritas Pelabuhan, Unit Penyelenggara Pelabuhan terkait dan Pemerintah Daerah;

f) Usulan jumlah frekuensi penerbangan, target penumpang yang akan diangkut dan waktu tempuh beserta jarak terbang;

g) Rincian perhitungan total biaya operasi pesawat udara yang dapat digunakan untuk melayani rute perintis beserta biaya operasi pesawat udara per rute perintis; dan

h) Untuk rute lama (existing) yang diusulkan kembali wajib menyampaikan hasil evaluasi pelaksanaan angkutan udara perintis.

7.3. Pelaksanaan Angkutan Laut Perintis

Pada angkutan laut perintinsi belum diatur mengenai mekanisme penggantian perjalanan yang dibatalkan.

Berikut adalah rinciannya:

1. Kegiatan angkutan laut perintis dilaksanakan berdasarkan rute, target frekuensi pelayaran, dan target penumpang yang ditetapkan Direktur Jenderal dan dilaksanakan setelah kontrak ditandatangani sesuai dengan ketentuan peraturan perundangundangan.

2. Pelaksanaan angkutan laut perintis dilaksanakan sesuai dengan jadwal pelayaran yang telah ditetapkan dalam kontrak.

3. Dalam pelaksanaan pelayaran sebagaimana dimaksud pada ayat (2) apabila terjadi pembatalan pelayaran harus segera diganti pelayaran paling lambat 7 (tujuh) hari kalender.

4. Apabila penggantian pelayaran sebagaimana dimaksud pada ayat (3) tidak dilaksanakan sampai dengan 7 (tujuh) hari kalender maka dikenakan denda sesuai dengan kontrak yang telah disepakati.

5. Pengenaan denda sebagaimana dimaksud pada ayat (4) dikenakan apabila pembatalan pelayaran akibat kesalahan Pelaksana Angkutan Laut Perintis.

\subsection{Koordinator Wilayah}

Koordinator wilayah adalah Kepala Unit Penyelenggara Pelabuhan yang ditunjuk untuk mengkoordinasikan penyelenggaraan angkutan udara perintis dan/atau subsidi angkutan udara kargo pada wilayah yang ditentukan. Koordinator wilayah dapat melakukan penyesuaian penyelenggaraan angkutan laut perintis dalam hal mengusulkan perubahan rute dan/atau penyesuaian frekuensi angkutan laut perintis penumpang pada tahun anggaran berjalan. Perubahan rute dan frekuensi tidak boleh melebihi anggaran yang telah ditetapkan. Usulan perubahan rute diajukan kepada Direktur Jenderal dengan dilengkapi data dukung dan berasal dari instansi terkait. Perubahan rute dilaksanakan setelah mendapat persetujuan Direktur Jenderal.

Koordinator Wilayah berkewajiban untuk:

a. Menyampaikan persiapan dan pelaksanaan angkutan laut perintis, subsidi angkutan laut perintis dan/atau subsidi biaya angkutan bahan bakar minyak dan jadwal pelayaran kepada Direktur Angkutan laut dan Kepala Kantor Syahbandar dan Otoritas Pelabuhan;

b. Melaksanakan pengawasan pelaksanaan angkutan laut perintis, subsidi angkutan laut dan/atau subsidi biaya angkutan bahan bakar minyak sesuai dengan kontrak termasuk membentuk tim pengawas angkutan laut perintis pada wilayah cakupannya;

c. Melaporkan hasil pengawasan sebagaimana dimaksud dalam huruf b kepada Direktur Jenderal cq. Direktorat Angkutan Laut dan tembusan kepada Kepala Kantor Syahbandar dan Otoritas Pelabuhan setiap 1 (satu) bulan sebagaimana format laporan yang merupakan bagian tidak terpisahkan dari Peraturan Menteri ini yang dapat dilakukan secara manual atau melalui jaringan internet;

d. Melakukan evaluasi penyelenggaraan angkutan laut perintis, subsidi angkutan udara laut dan/atau subsidi biaya angkutan bahan bakar minyak setiap 6 (enam) bulan serta melaporkan kepada Direktur Jenderal Perhubungan Laut dan Kepala Kantor Syahbandar dan Otoritas Pelabuhan; dan

e. Mempersiapkan kesinambungan pelaksanaan program angkutan udara perintis dan/atau subsidi angkutan udara kargo pada tahun berikutnya.

Berikut ini disajikan gambaran struktur organisasi pelaksanaan angkutan laut perintis. 


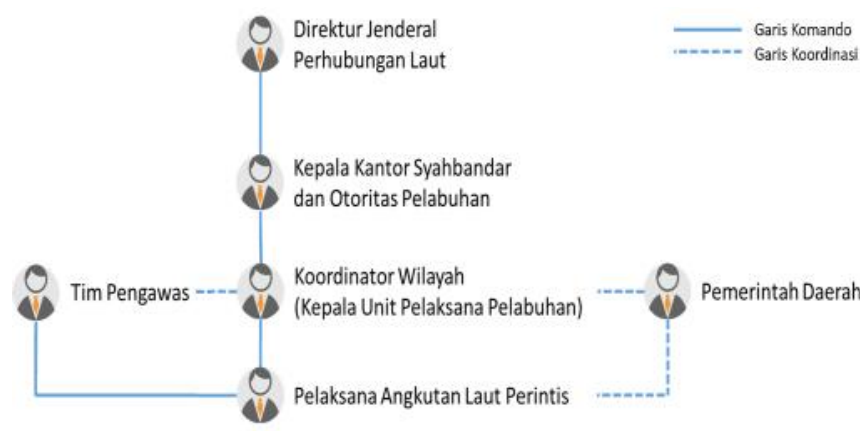

Gambar Struktur Organisai Pelaksanaan Angkutan Laut Perinti Sumber: Analisis Konsultan, 2018

\subsection{Evaluasi Rute Perintis}

Pada penyelenggaraan angkutan laut perintis tidak ada penjelasan mengenai evaluasi rute perinis yang harus dilakukan, yang dijelaskan hanyalah pelaporan perlaksanaan kegiatan perintis oleh operator kepada pemerintah pusat.

Berikut ini adalah penjabaran evalauasi perintis untuk angkutan laut:

1. Evaluasi pelaksanaan pelayanan angkutan udara perintis dan subsidi angkutan laut perintis dilakukan sekurang-kurangnya 1 (satu) tahun sekali oleh Direktur Jenderal Perhubungan Laut, Kantor Syahbandar dan Otoritas Pelabuhan, Koordinator Wilayah dengan melibatkan Unit Pelaksana Pelabuhan dan Pemerintah Daerah.

2. Evaluasi pelaksanaan angkutan laut perintis dilaksanakan berdasarkan:

a. Fungsi keperintisan;

b. Kinerja penyelenggaraan angkutan laut perintis;

c. Pelaporan Kegiatan Angkutan Laut Perintis yang dilakukan secara berkala setiap bulan yang dapat dilakukan secara manual atau elektronik;

d. Log Book; dan

e. Pertumbuhan ekonomi dan peningkatan pembangunan insfraktuktur daerah.

3. Hasil evaluasi merupakan dasar:

a. Penetapan sebagai rute perintis dan rute Subsidi Angkutan Laut Perintis pada tahun berikutnya; atau

b. Perubahan rute perintis menjadi rute komersial; atau

c. Penghapusan rute perintis.
7.5.1. Kriteria Perubahan Rute Perintis Menjadi Komersial Selain itu pada PM 79/2017 juga dijelaskan mengenai kriteria perubahan rute perintis menjadi rure komersial. Sebelumnya pada peraturan yang telah dihapuskan yaitu PM 9/2016 juga dijelaskan hal yang sama namun dengan kriteria yang berbeda yaitu:

1. Kebutuhan jasa angkutan meningkat dengan ada load factor di atas 70\% dan frekuensi lebih dari 4 (empat) kali per minggu.

2. Kemampuan daya beli masyarakat tinggi.

3. Tarif perintis telah sesuai dengan tarif angkutan niaga berjadwal, dan/atau

4. Terdapat badan usaha angkutan niaga berjadwal yang bersedia untuk melayani rute tersebut secara komersial dan berkesinambungan.

Namun pada PM 79/2017 penggunaan indikator load factor dalam mengevaluasi rute perintis menjadi rute komersial dihapuskan. Hal ini sejalan dengan fungsi penyelenggaraan perintis pada dasarnya bukanlah mencari keuntungan, tetapi untuk meningkatkan konektivitas dan aksesibilitas terutama agar masyarakat merasakan kehadiran negara pada daerah tertinggal, terdepan, dan terluar. Sehingga load factor ini bukan digunakan sebagai indikator finansial tetapi lebih digunakan sebagai indikator efisiensi terutama dalam aspek biaya.

Perubahan rute perintis menjadi rute komersial pada angkutan laut perintis dilakukan setelah memenuhi ketentuan sebagai berikut:

a. Terpenuhinya target penumpang dan frekuensi yang telah ditetapkan dalam kontrak;

b. Besaran tarif perintis telah mendekati tarif angkutan laut niaga berjadwal; dan/atau

c. Terdapat badan usaha angkutan laut niaga berjadwal yang melayani rute tersebut secara komersial dan berkesinambungan.

7.5.2. Kriteria Penghentian Penyelenggaraan Angkutan Perintis

Penyelenggaraan angkutan laut perintis penumpang dihentikan apabila:

a. Pada rute tersebut sudah tersedia moda transportasi lain dengan kapasitas dan waktu tempuh yang memadai dan pelayanan yang berkesinambungan; atau

b. Pada rute tersebut sudah dilayani angkutan laut niaga berjadwal sampai dengan akhir tahun anggaran kegiatan angkutan laut perintis.

8. Hasil Tinjau Ulang Pengongoperasian dan Jaringan Angkutan Laut Perintis

8.1. Evaluasi Terhadap Jaringan Trayek Angkutan Laut Perintis

Dari hasil evaluasi terhadap jaringan trayek angkutan laut perintis yang sudah beroperasi ditemukan beberapa 
masalah yang menyebabkan penyelenggaraan angkutan laut perintis belum optimal.

Pertama, terkait realisasi lamanya waktu layar atau round voyage dapat dikatakan terlalu lama yaitu berkisar antara 11 - 19 hari pelayaran. Lamanya round voyage kapal-kapal perintis ini dirasakan masih belum memadai untuk memenuhi kebutuhan masyarakat, terutama yang berada di daerah-daerah Tertinggal, Terdepan, dan Terluar.

Berdasarkan hasil analisis disparitas harga barang pokok diperoleh bahwa disparitas harga yang cukup tinggi terjadi di wilayah timur Indonesia antara lain di Tanah Bumbu, Kepulauan Anambas, Natuna, Tanjung Pinang, Bima, Ambon, Kepuluauan Aru, Maluku Barat Daya, Seram Bagian Barat, Tual, Halmahera Barat, Halmahera Selatan, Halmahera Tengah, Halmahera Timur, Halmahera Utara, Kepulauan Sula, Pulau Morotai, Pulau Taliabu, Ternate, Asmat, Boven Digul, Mappi, Merauke, dan Mimika. Disparitas tertinggi yaitu sebesar 114\% terjadi pada tahun 2017 untuk bahan pokok cabai merah di wilayah Maluku, tepatnya di Kepulauan Aru, Maluku Barat Daya, dan Tual. Hal ini kemungkinan terjadi karena masih lamanya waktu round voyage angkutan laut perintis di daerah tersebut, sebut saja trayek R66, R84, dan R85 dengan lama round voyage 15 - 16 hari. Meskipun demikian, adanya angkutan laut perintis dapat membantu menjaga kestabilan harga bahan pokok di daerah yang disinggahi. Sebagai contoh, untuk bahan pokok jenis beras perkembangan disparitas harga dalam periode 2016 hingga 2018 cenderung semakin menurun setiap tahunnya. Hal ini menjelaskan bahwa keberadaan angkutan laut perintis memiliki peranan yang penting dalam menjaga kestabilan harga bahan pokok.

Kedua, utilisasi penggunaan kapal perintis, cenderung dapat dikatakan tidak efisien. Dari sampel trayek yang diamati didapat bahwa rata-rata passenger factor untuk setiap voyage berada di rentang $1 \%$ hingga $13 \%$ saja dengan tingkat keterisian penumpang maksimum pada satu voyage sebesar $45.5 \%$. Sementara, rata-rata load factor untuk setiap voyage berada di rentang $0.2 \%$ hingga $28 \%$ dengan tingkat keterisian barang maksimum pada satu voyage sebesar $103.5 \%$. Sehingga masih diperlukan penyesuaian ukuran kapal dengan tetap memperhatikan standar keselamatan.

Ketiga, beberapa rute yang dilalui angkutan laut perintis tidak memenuhi kriteria fungsi keperintisan sebagaimana yang dijelaskan pada Peraturan Pemerintah Nomor 20

Tahun 2010 tentang Angkutan di Perairan pasal 71 ayat 1 dan 2. Berdasarkan evaluasi, masih ditemukan pelayanan trayek angkutan laut perintis yang tumpang tindih dengan pelayanan trayek angkutan komersil, moda jalan (jalan raya), trayek angkutan laut perintis lainnya. Selain itu, ditemukan pula trayek angkutan laut perintis yang didominasi oleh daerah yang sudah berkembang atau cenderung maju.

Berdasarkan identifikasi konektivitas antara trayek angkutan laut perintis dengan simpul pelabuhan tol laut, tampak bahwa masih ada ketimpangan konektivitas antara jaringan angkutan laut perintis dengan simpul pelabuhan tol laut. Konektivitas simpul pelabuhan tol laut dengan angkutan laut perintis paling tinggi ada di Pelabuhan Saumlaki, dengan 16 trayek terkoneksi dengan pelabuhan ini. Sementara itu masih ada 15 simpul pelabuhan tol laut yang belum terkoneksi dengan trayek angkutan laut perintis sama sekali.

Artinya, belum ada integrasi jaringan trayek angkutan laut perintis di sini, hal ini mungkin dapat menjelaskan mengapa permasalahan lamanya round voyage dan utilisasi kapal perintis menjadi tidak optimal. Adanya ruas trayek yang sudah dilayani angkutan lain dapat mengurangi bangkitan pergerakan dan menambah daerah yang harus dikunjungi angkutan laut perintis yang berujung pada operasi angkutan laut perintis yang tidak efisien.

Sementara, terkait penilaian kinerja dari sisi pengguna angkutan laut, secara keseluruhan dari sebagian besar responden menyatakan bahwa kinerja angkutan laut perintis saat ini sudah cukup baik, namun terdapat beberapa aspek yang perlu diperbaiki antara lain berkaitan dengan fasilitas di pelabuhan, frekuensi keberangkatan yang belum memadai, rute pelayaran, waktu tunggu, waktu layar, dan jumlah kapal.

8.2. Evaluasi Terhadap Sarana, Prasarana, Dan Teknologi Angkutan Laut Perintis

Potensi wilayah pada hinterland angkutan laut perintis yang digambarkan oleh PDRB atas dasar harga konstan menunjukkan peningkatan setiap tahunnya, sehingga dapat dikatakan bahwa estimasi proyeksi muatan angkutan laut perintis pun akan meningkat sejalan dengan pertumbuhan PDRB wilayahnya. Hasil proyeksi muatan angkutan laut perinis hingga tahun 2048 menunjukkan bahwa ukuran kapal eksisting saat ini tidak mampu mengakomodasi jumlah penumpang dan barang di atas kapal hasil proyeksi. Selain itu, didapatkan perubahan kebutuhan dimensi dari hasil proyeksi kebutuhan kapal.

Permasalahan terkait utilisasi kapal perintis yang belum efisien terjadi karena ketidaksesuaian ukuran kapal yang digunakan sehingga masih diperlukan penyesuaian ukuran kapal dengan tetap memperhatikan standar keselamatan dan jumlah armada kapal yang sudah tersedia. Hal ini penting dilakukan demi tercapainya cost effectiveness, selain dari penyesuaian jaringan trayek, penyesuaian spesikasi kapal yang digunakan dapat mengurangi biaya operasi kapal. Selain itu masih ditemukan kapal yang docking di pelabuhan terlalu lama karena mengalami kerusakan. Tentunya hal ini dapat 
mengurangi efisiensi pelabuhan terutama di pelabuhan pangkalan yang melayani angkutan komersil dan tol laut.

\subsection{Evaluasi Terhadap Manajemen dan} Pengelolaan Angkutan Laut Perintis

Penyelenggaraan angkutan laut perintis saat ini dapat dikatakan belum optimal dalam berbagai aspek terutama terkait jaringan trayek angkutan laut perintis.

Permasalahan ini kemungkinan muncul karena manajemen dan pengelolaan angkutan laut perintis yang belum baik. Seperti ditemukannya ruas jaringan trayek angkutan laut perintis yang tidak memenuhi fungsi keperintisan karena tumpang tindih dengan angkutan lain atau penempatan pelabuhan singgah yang tidak sesuai kriteria menunjukkan masalah integrasi jaringan. Hal ini terjadi karena setiap trayek dikelola oleh operator yang berbeda-beda sehingga dibutuhkan suatu fungsi yang dapat mengkoordinasi penyelenggaraan angkutan laut perintis berbasis wilayah yang menjadi perantara pemerintah pusat dan operator. Kemungkinan penyebab lainnya, yaitu kurangnya pengawasan dalam penambahan rute hasil usulan pemerintah daeah yang cenderung diterima tanpa dievaluasi lebih dalam.

Terkait utilisasi kapal yang belum efisien kemungkinan dapat terjadi karena potensi daerah yang memerlukan perintis tidak di respon secara baik oleh daerah lain karena penyelenggaraan perintis yang cenderung bersifat silo-silo.

Meskipun evaluasi penyelenggaraan angkutan laut perintis selalu dilakukan setiap tahun, permasalahanpermasalahan sebagaimana yang dijabarkan di atas selalu muncul dan belum membaik. Hal ini terjadi karena ketentuan-ketentuan teknis mengenai penyelenggaraan perintis belum banyak dituangkan ke dalam peraturan, sehingga pengelolaanya masih belum bisa diawasi dengan baik. Dalam hal ini belum ada peraturan mengenai angkutan laut perintis yang membahas ketentuan yang lebih detail mengenai evaluasi rute perintis, yang ada hanya penyelenggaraan perintis yang sifatnya masih umum. Terlebih penyelenggaraan perintis saat ini dilakukan dengan kontrak per tahun menyebabkan evaluasi dan peningkatan kinerja belum bisa dilaksanakan secara optimal.

Sistem kontrak tahunan berdasarkan tahun tunggal membuat ada waktu-waktu kapal yang tidak beroperasi karena proses lelang dan kontrak belum selesai. Dengan kontrak jangka panjang akan merangsang pengusaha membangun kapal baru dan memperbaiki standar pelayanan angkutan perintis serta memudahkan pihak penyelenggara untuk membeli kapal dalam melayani angkutan laut perintis. Manfaat lainnya dari sistem kontrak jangka panjang adalah akan meningkatkan kepercayaan perbankan dan lembaga pembiayaan nonbank terhadap operator angkutan laut perintis guna memperoleh kredit. Selain memudahkan pengadaan kapal, sistem kontrak jangka panjang akan menjamin perawatan kapal perintis. Jika kontrak dilaksanakan per tahun maka operator pelayaran kesulitan merawat kapal sesuai dengan jadwal dan meningkatkan pelayanan angkutan laut perintis kepada penumpang maupun barang.

\section{Rekomendasi}

Berdasarkan hasil pengumpulan data dan analisis, kebijakan pelayaran angkutan laut perintis di Indonesia sebaiknya diarahkan ke empat aspek, yaitu terkat jaringan trayek angkutan laut perintis; sarana, prasarana, dan teknologi; manajemen dan pengelolaan; serta regulasi angkutan laut perintis.

Adapun rekomendasi yang dapat diberikan untuk pengoperasian dan jaringan angkutan laut perintis yang optimum di wilayah terdepan, terluar, dan terisolir, adalah antara lain:

1. Terkait optimalisasi jaringan trayek angkutan laut perintis:

- Penjabaran kriteria penetapan rute perintis terutama fungsi perintis untuk menghubungkan daerah terpencil dan daerah tertinggal;

- Penjabaran kriteria evaluasi penyelenggaraan rute angkutan laut perintis terkait perubahan rute perintitis menjadi rute komersial dan penghapusan rute perintis;

- Penetapan target penumpang dan frekuensi angkutan laut perintis yang harus dipenuhi dalam kontrak;

- Evaluasi pelaksanaan angkutan laut perintis berdasarkan fungsi keperintisan, kinerja penyelenggaraan angkuran laut perintis, pelaporan realisasi pelaksanaan kegiatan perintis secara berkala, dan pertumbuhan ekonomi dan peningkatan pembangunan infrastruktur daerah;

- Integrasi jaringan dengan melakukan re-routing berdasarkan hasil evaluasi kinerja angkutan laut perintis; dan

- Angkutan laut perintis sebagai feeder tol laut.

2. Terkait sarana, prasarana, dan teknologi:

- Penggunaan spesifikasi kapal yang lebih efisien sesuai hasil evaluasi berkala yang dilakukan dengan memperhatikan jumlah armada kapal yang sudah tersedia;

- Pembangunan fasilitas pelabuhan khususnya fasilitas singgah pada pelabuhan perintis yang belum memiliki fasilitas pelabuhan namun dapat disinggahi kapal perintis;

- Penyediaan kapal-kapal kecil untuk pelaksanaan ship to ship pada pelabuhan yang tidak bisa disinggahi kapal perintis karena hambatan alam; 
- Penyediaan kapal pengganti untuk kapal yang sedang docking karena masalah pemeliharaan;

- Penggunaan skema KPBU dalam pembangunan dan perbaikan pelabuhan perintis; dan

- Pemeliharaan kapal perintis menjadi tanggung jawab operator yang dimuat dalam kontrak jangka panjang (multiyear contract);

3. Terkait manajemen dan pengelolaan angkutan laut perintis:

- Pembentukan koordinator wilayah untuk mengkoordinasikan penyelenggaraan akutan laut perintis dan/atau subsidi angkutan laut perintis pada wilayah yang ditentukan;

- Penetapan prosedur dan persyaratan dalam mengusulkan rute angkutan laut perintis baik rute lama (eksisting) dan rute baru;

- Penyelenggaraan perintis dengan sistem kontrak jangka panjang (multiyears contract) dengan pelelengan terbuka; dan

- Pembentukan regulasi yang mengatur penyelenggaraan angkutan laut perintis terutama terkait aspek penjabaran kriteria penyelenggaraan perintis, kinerja dan evaluasi pelaksanaan angkutan laut perintis, dan tata cara pengusulan rute angkutan laut perintis.

4. Terkait belum adanya peraturan mengenai angkutan laut perintis yang membahas ketentuan detail mengenai penjabaran kriteria penyelenggaraan perintis, kinerja dan evaluasi pelaksanaan angkutan laut perintis, dan tata cara pengusulan rute angkutan laut perintis, maka maka angkutan laut perintis dapat mengacu kepada peraturan angkutan udara perintis PM 79/2017 yang dipandang sudah cukup baik.

5. Perlu diketahui bahwa rekomendasi re-routing pada studi ini masih memerlukan penyempurnaan sehingga pada studi selanjutnya dapat melibatkan hal-hal tambahan sebagai berikut:

- Kondisi jalan raya yang tersedia pada ruas jaringan angkutan laut perintis yang berhimpitan dengan jalan raya;

- Evaluasi perbandingan ruas jaringan angkutan laut perintis dengan angkutan laut komersil swasta dan angkutan penyeberangan (perintis dan swasta);

- Evaluasi frekuensi pelayaran angkutan laut dan angkutan penyeberangan;

- Kondisi infrastruktur pelabuhan singgah angkutan laut perintis; dan

- Kajian hubungan sosial budaya pada wilayah yang disinggahi angkutan laut perintis serta pengaruhnya terhadap bangkitan dan tarikan pergerakan.

\section{DAFTAR PUSTAKA}

\section{A. Penelitian}

Bay M. Hasani. 2017. Pelaksana Tugas Direktur Jenderal Perhubungan Laut. Pidato Pembukaan Rapat Koordinasi Nasional (Rakornas) Angkutan laut perintis. Selasa, 3 Oktober. Jakarta.

Badan Litbang Perhubungan. 2012. Kebijakan Pengembangan Angkutan Laut Perintis dalam Rangka Meningkatkan konektivitas dan Mendukung Pengentasan Kemiskinan pada Daerah Tertinggal. Roundtable discussion. 24 November. Jakarta

Badan Litbang Perhubungan. 2013. Penyusunan Kriteria di Bidang Trasportasi Laut Untuk Peningkatan Pelayanan, Keselamatan dan Keamanan. Focus Group Discussion. 4 November. Jakarta

Departemen Perhubungan dan Lembaga Ketahanan Nasional. 1992. Kajian Pengembangan Pelayaran Rakyat. Jakarta: Departemen Perhubungan dan Lembaga Ketahanan Nasional.

Direktorat Kawasan Khusus dan Daerah Tertinggal, Kementerian Perencanaan Pembangunan Nasional (PPN)/ Badan Perencanaan Pembangunan Nasional (BAPPENAS) berdasarkan surat No. 2421/Dt.7.2/04/2015.

Ditjen Perhubungan Laut. 1997. Indikator Kinerja Sub Sektor Transportasi Laut. Jakarta. Departemen Perhubungan.

Hermawan, Ferry, dan Hanggoro Tri Cahyo A. 2008. Pengembangan Trayek Angkutan Perintis di Wilayah Karesidenan Pekalongan Metode SIGAHP. Prosiding INSAHP5, Teknik Industri, Universitas Diponegoro.

Johannes, Standy, M. Ruslin Anwar, dan Eddi Basuki. 2012. Proyeksi Jumlah Pergerakan Dalam Menentukan Kapasitas dan Jumlah Armada Perintis Kabupaten Maluku Barat Daya. Jurnal Teknologi Volume 9. No.2.

LP3MT STMT Trisakti Jakarta. 2011. Kajian Kinerja Pelayanan Angkutan Laut Perintis Dalam Upaya Penataan Angkutan Laut Perintis (Studi Kasus Trayek R5 Pelabuhan Pangkal Tg. Pinang.

Siahaan, Denny L. 2013. Diskusi bertema Penyusunan Kriteria di Bidang Trasportasi Laut Untuk Peningkatan Pelayanan, Keselamatan dan Keamanan. Focus Group Discussion Badan Litbang Kementerian Perhubungan. Senin 4 November. Jakarta.

Soegoto, Eddy Suryanto. 2010. Faktor-Faktor yang Mempengaruhi Pelabuhan di KTI Disinggahi Armada Perintis. Majalah Ilmiah Unikom. Vol.7 No.1.

Wahyono, Efendi, Yuda B. Tangkilisan, Djokko Marihandono. 2014. Pelayaran Perintis Dalam Integrasi Nasional dan Perkembangan Daerah Perbatasan, Terpencil, dan Tertinggal 1974-2012. 
Laporan Hasil Penelitian Fundamental Universitas Terbuka.

\section{B. Publikasi Berita/Informasi}

Annual Report PT. PELNI Tahun 2016.

Dunia Maritim, 5-6/xxxiv/Mei-Juni 1984.

Dunia Maritim, 3/xlv/April-Mei 1995.

Info Kajian Bappenas. 2011.

Kabupaten Morowali Utara Dalam Angka. 2017. Badan Pusat Statistik

Kabupaten Sambas Dalam Angka. 2017. Badan Pusat Statistik

Kabupaten Poso Dalam Angka. 2018. Badan Pusat Statistik

Kota Padang Dalam Angka. 2017. Badan Pusat Statistik.

Kota Padang Dalam Angka. 2018. Badan Pusat Statistik.

Kota Surabaya Dalam Angka. 2017. Badan Pusat Statistik.

Kota Ternate Dalam Angka. 2018. Badan Pusat Statistik.

Kota Merauke Dalam Angka. 2017. Badan Pusat Statistik.

Pusat Informasi Harga Pangan Strategis Nasional. 2018.

Subsidi untuk pelayaran perintis pertahun mencapai $\mathrm{Rp}$ 400 milyar pertahun. www.bumn.go.id.

Subsidi untuk Pelayaran nasional tingkat ekonomi melalui PT. Pelni mencapai Rp 897 milyar. www. tempo.com.

Wibawa, Hendra. 2009. http://saifulanamfoundation.blogspot.com/2009/04 loperator-minta-kontrak.html.

\section{Regulasi}

Undang-Undang Nomor 26 Tahun 2007 tentang Penataan Ruang.

Undang-Undang Nomor 17 Tahun 2018 tentang Pelayaran.

Peraturan Pemerintah Nomor 20 Tahun 2010 tentang Angkutan di Perairan.

Peraturan Pemerintah Nomor 22 Tahun 2011 tentang Perubahan Peraturan Pemerintah Nomor 20 Tahun 2010.

Peraturan Menteri Perhubungan Nomor PM 93 Tahun 2013 tentang Penyelenggaraan dan Pengusahaan Angkutan Laut.

Peraturan Menteri Perhubungan Nomor PM 9 Tahun 2016 tentang Kriteria dan Penyelenggaraan Kegiatan Angkutan Udara Perintis.

Peraturan Menteri Perhubungan Nomor PM 2 Tahun 2017 tentang Komponen Penghasilan dan Biaya Yang Diperhitungkan Dalam Kegiatan Penyelenggaraan Angkutan Laut Perintis Melalui Mekanisme Pelelangan Umum.

Peraturan Menteri Perhubungan Nomor PM 15 Tahun 2017 tentang Komponen Penghasilan dan Biaya Yang Diperhitungkan Dalam Kegiatan Penyelenggaraan Angkutan Laut Perintis Melalui Mekanisme Penugasan.
Peraturan Menteri Perhubungan Nomor PM 79 Tahun 2017 tentang Kriteria dan Penyelenggaraan Kegiatan Angkutan Udara Perintis dan Subsidi Angkutan Udara Kargo.

Peraturan Menteri Perhubungan Nomor PM 48 Tahun 2018 tentang Penyelenggaraan Kegiatan Publik Kapal Perintis.

Keputusan Menteri Perhubungan Nomor. KM 49 Tahun 2005 tentang Sistem Transportasi Nasional (SISTRANAS).

\section{Kunjungan Instansi}

Dinas Perdagangan Kota Padang.

Dinas Perdagangan Kota Ternate.

Dinas Perdangan Provinsi Jawa Timur.

Dinas Perdangan Provinsi Kalimantan Barat.

Diretorat Lalu Lintas Agkutan Laut, Direktorat Jenderal Perhubungan.

PELNI (Persero).

PT. Aksar.

Kantor Syahbandar dan Otoritas Pelabuhan Teluk Bayur

Kantor Syahbandar dan Otoritas Pelabuhan Sintete

Kantor Syahbandar dan Otoritas Pelabuhan Tanjung

Perak

Kantor Syahbandar dan Otoritas Pelabuhan Poso Kantor Syahbandar dan Otoritas Pelabuhan Ternate Kantor Syahbandar dan Otoritas Pelabuhan Merauke 